\title{
STUDY OF GaAs(Ti ) THIN FILMS AS CANDIDATES FOR IB SOLAR CELLS MANUFACTURING
}

\author{
S.Silvestre ${ }^{1}$, A.Boronat ${ }^{1}$, L.Castañer ${ }^{1}$, \\ D. Fuertes Marrón ${ }^{2}$, A.Martí ${ }^{2}$ and A.Luque \\ ${ }^{1}$ MNT- Electronic Engineering Department, Universitat Politècnica de Catalunya \\ C/ Jordi Girona 1-3, Campus Nord UPC, 08034 Barcelona, Spain \\ 2 Instituto de Energía Solar, Universidad Politécnica de Madrid \\ ETSIT de Madrid, Ciudad Universitaria sn, 28040 Madrid, Spain
}

\begin{abstract}
Thin films of GaAs(Ti) have been deposited by sputtering on glass and $n$ GaAs substrates under different process conditions. Optical characteristics of these samples have been analyzed to study the potential of this material in intermediate Band solar cell manufacturing.

\section{INTRODUCTION}

The development of intermediate band (IB) solar cells is nowadays one of the most attracting target in the field of solar cell manufacturing [1-2].

Quantum Dots IB solar cells have been developed in the past years [3], and different materials have been described as potential bulk IB materials: $\mathrm{Si}$ doped with $\mathrm{Ti}$ [4], Ti-substituted GaAs and GaP [5-7], III-V and II-VI alloys, in which a small amount of $\mathrm{V}$ and $\mathrm{VI}$ anions are replaced with isovalent $\mathrm{N}$ and $\mathrm{O}$ [8]

In this work we report the deposition of $\mathrm{GaAs}$ (Ti) thin films by sputtering, having relatively low $\mathrm{Ti}$ concentration, which could be useful for realizing the Intermediate Band Solar Cell concept.
\end{abstract}

\section{SPUTTERING PROCESS DESCRIPTION}

A set of thin films have been deposited on glass and n_GaAs substrates under different conditions in a RF Sputtering System :ESM100 Edwards \& RFS5 Generator$300 \mathrm{~W}$. Two different targets have been used in these processes:

- GaAs (99\%)-Ti (0.5\%), Purity ; 99,999\%, Size: 4" Diameter $\times 0.125$ " thick from Angstrom Sciences.

- $\operatorname{GaAs}(\mathrm{n})<100>$, having a Si impurity concentration of $7 \times 10^{17} \mathrm{~cm}^{-3}$. Size: 4 " Diameter $\times 325 \mu \mathrm{m}$.

A first sputtering process was carried out and thin films of $\mathrm{GaAs}(\mathrm{Ti})$, ranging from $60 \mathrm{~nm}$ to $400 \mathrm{~nm}$ thick, were grown by sputtering. The process conditions were: 1) Chamber pressure $510^{-3} \mathrm{mbar}$; 2) Ar flux $10 \mathrm{sccm}$; 3) The R.F. input power $50 \mathrm{~W}$ and $100 \mathrm{~W}$. 4) Deposited at room temperature. The sputtering rates were in the range of $550-800 \mathrm{~nm} \mathrm{~h}^{-1}$.

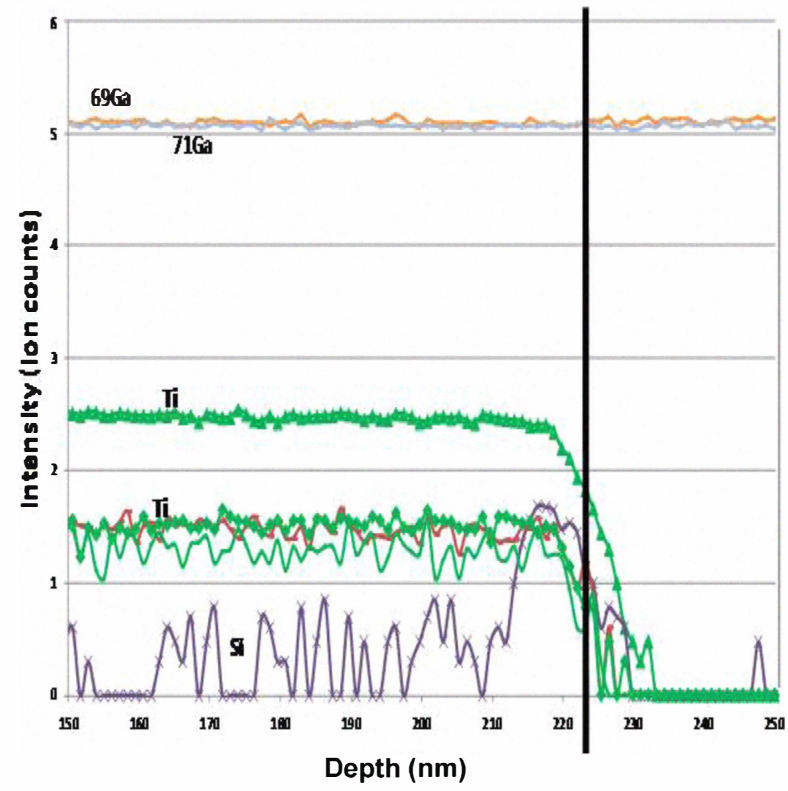

Figure 1 Tof-SIMS of GaAsTi on n-GaAs substrate.

TOF-SIMS (Time-Of-Flight Secondary Ion Mass Spectroscopy) measurements have been carried out in all samples. Ti profiles show good uniformity and constant concentration along the layer deposited, this trend has been observed in all samples analyzed (see Fig. 1).

$X$-ray diffraction (XRD) measurements have shown that a thermal annealing can help to favoring crystallization of sputtered $\mathrm{GaAs}$ thin films [10]. The amorphous network of GaAs films, obtained by sputtering, also decreases by increasing the substrate temperature [11]. For this reason we tried a second sputtering process of $\mathrm{GaAs}(\mathrm{Ti})$ on glass substrates. The process conditions were the same that in the first sputtering process except that the R.F. input power: $50 \mathrm{~W}, 100 \mathrm{~W}$ and $200 \mathrm{~W}$, and the deposition temperatures: $20^{\circ} \mathrm{C} 200^{\circ} \mathrm{C}$ and $400^{\circ} \mathrm{C}$, were varied. Table 1 summarizes the process conditions. 


\begin{tabular}{|c|c|c|c|}
\hline Sample & Structure & $\begin{array}{c}\text { R.F. } \\
\text { power } \\
(\mathrm{W})\end{array}$ & $\begin{array}{c}\text { deposition } \\
\text { temperatures } \\
\left({ }^{\circ} \mathrm{C}\right)\end{array}$ \\
\hline PC7A & n_GaAs ( ref) & 50 & 20 \\
\hline PC7B & $\begin{array}{c}\text { glass- } \\
\text { GaAsTi- } \\
\text { n_GaAs }\end{array}$ & 50 & 20 \\
\hline $\begin{array}{c}\text { PC } \\
\text { Temp1 }\end{array}$ & glass-GaAsTi & 200 & 20 \\
\hline $\begin{array}{c}\text { PC } \\
\text { Temp2 }\end{array}$ & glass-GaAsTi & 200 & 400 \\
\hline $\begin{array}{c}\text { PC } \\
\text { Temp3 }\end{array}$ & glass-GaAsTi & 100 & 20 \\
\hline $\begin{array}{c}\text { PC } \\
\text { Temp4 }\end{array}$ & glass-GaAsTi & 100 & 200 \\
\hline
\end{tabular}

Table 1 Samples and sputtering conditions.

\section{RESULTS OBTAINED}

Sub band-gap absorption has been observed in samples obtained in both sputtering processes. Absorptance peaks around $1.3 \mathrm{eV}$ have been detected in the different measurements described below.

Photo reflectance (PR) measurements have been carried out, at the Instituto de Energía Solar- Universidad Politécnica de Madrid, for the different samples analyzed. The absorptance peaks shown (see Fig.2), seem to be the effect of interferences due to the $D C$ and $A C$ signal variations along the measurements, except in the case of sample PC Temp2, where the absorbance peak observed around $1.3 \mathrm{eV}$ can not be explained by these effects analyzing the first and second derivatives of the signal.

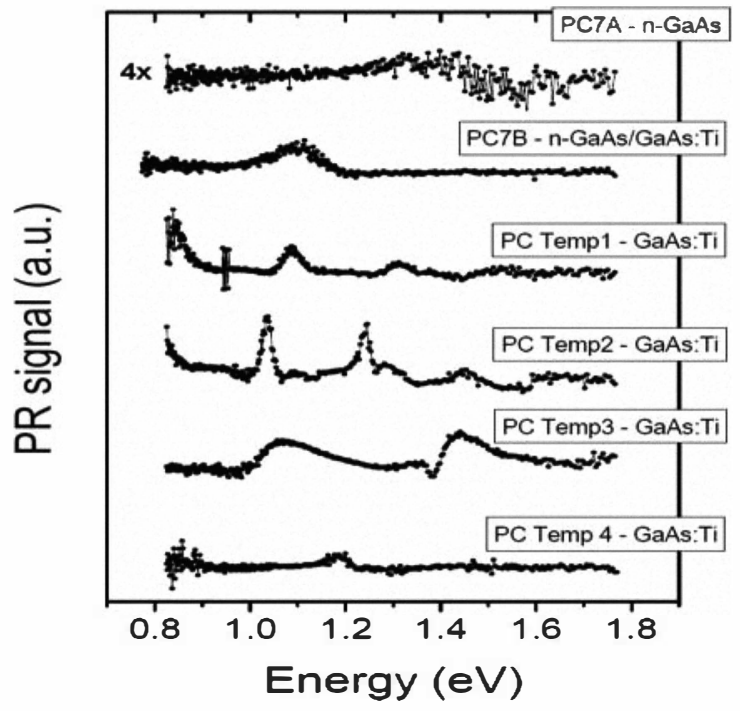

Figure 2 PR measurements.
Furthermore Fourier Transform InfraRed (FT-IR) measurements have also been carried out using a commercial Vertex 70 FT-IR Spectrometer, and an absorbance peak around $1.3 \mathrm{eV}$, below the crystalline GaAs energy gap, appears again for the sample PC Temp 2 (see Fig. 3).

\section{Absorbance}

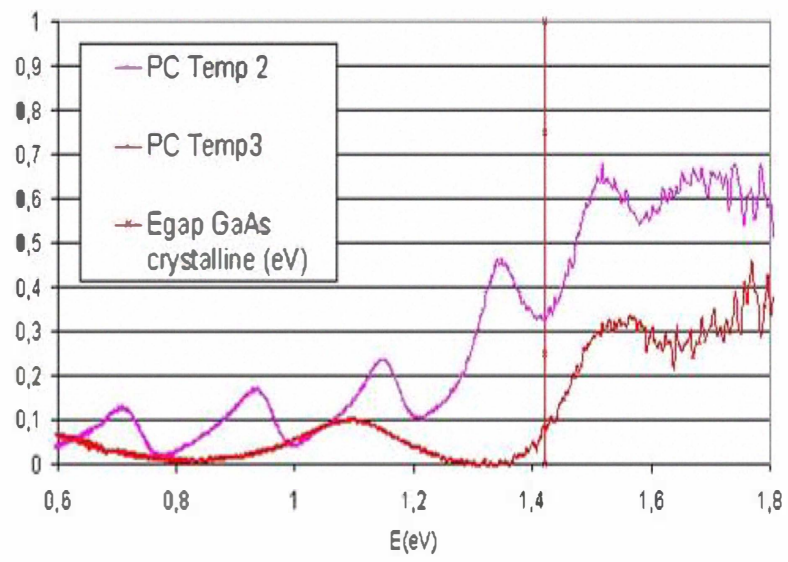

Figure 3 FT-IR measurements.

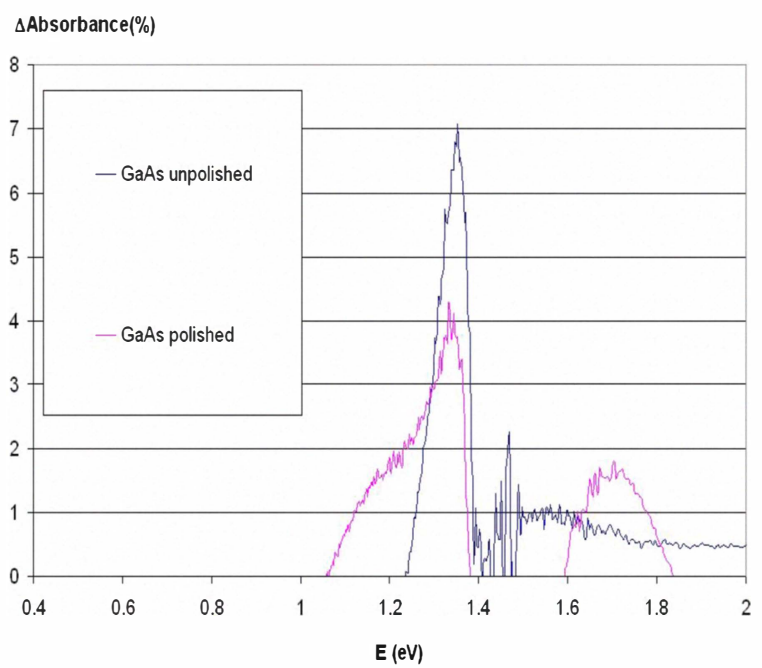

Figure 4 Difference of the absorbance of $\mathrm{GaAs}(\mathrm{Ti})$ on n_GaAs samples minus the absorbance of n_GaAs substrates alone.

Finally, absorption measurements have been performed using an UV-3600 UV-VIS-NIR spectrophotometer, for two samples of $\mathrm{GaAs}(\mathrm{Ti})$ thin films deposited in the first sputtering process on $\mathrm{n}$ _ GaAs substrates.

We have detected some differences between absorbances of n_GaAs (polished and unpolished) and absorbances of the same substrates having the deposited GaAsTi thin film. Two peaks at $1.33 \mathrm{eV}$ and $1.35 \mathrm{eV}$ can 
be clearly observed in samples having the $\mathrm{GaAs}(\mathrm{Ti})$ layer (see Fig.4). A second absorbance peak at $1.7 \mathrm{eV}$ is also observed in the polished sample having the the $\mathrm{GaAs}(\mathrm{Ti})$ layer.

\section{CONCLUSIONS}

Thin film of $\mathrm{GaAs}(\mathrm{Ti})$ have been deposited by sputtering on glass and $n$ GaAs substrates. Tof-SiMS measurements confirm that $\mathrm{Ti}$ profiles show good uniformity and constant concentration along the layers deposited in all cases.

Thin films of GaAs and GaAs(Ti) have been deposited by sputtering on slides under different process conditions. Optical Absorption is enhanced by $\mathrm{Ti}$ in all samples. Absorbance peaks, around $1.3 \mathrm{eV}$ and $1.7 \mathrm{eV}$, have been detected in samples of $n \_G a A s$ whit thin films of GaAs(Ti) on its surface.

\section{ACKNOWLEDGEMENT}

This work is partially supported by The Spanish Ministry of Education and Science under Consolider Ingenio 2010 Program, through the project GENESIS-FV (CSD20060004).

\section{REFERENCES}

[1] A.Luque and A.Martí, "The Intermediate Band Solar Cell: Progress Toward the Realization of an Attractive Concept "Adv. Mater. 22, 2010, pp.160-174.

[2] A.Luque, A.Martí, E.Antolín, E.Cánovas, P. G. Linares, C. Tablero, D. Fuertes Marrón, I.Tobías, M.Mendes, A. Mellor, M. Y. Levy, E. Hernández, C.R.Stanley, C.D.Farmer, R.P. Campion, S.V. Novikov, C.T. Foxon, R.Scheer, B. Marsen H.W.Schock, G. González, I. Martil, J.Olea, and D.Pastor "New approaches to the intermediate band solar cell concept", 24th European Photovoltaic Solar Energy Conference, 2009, pp.7-14.

[3] A. Luque, A. Martí, C. Stanley, N. López, L. Cuadra, D. Zhou, A. Mc-Kee, "General equivalent circuit for intermediate band devices: Potentials, currents and electroluminescence", Journal of Applied Physics 96, 2004 pp. 903-909.

[5] J. Olea, M. Toledano-Luque, D. Pastor, G.GonzalezDiaz, I. Martil," Titanium doped silicon layers with very high concentration", Journal of Applied Physics 104, 2008, 016105.

[6] P. Palacios, P. Wahnón, S. Pizzinato, J. C. Conesa, "Energetics of formation of TiGa3As4 and TiGa3P4 intermediate band materials", J. Chem. Phys. 124, 2006, pp. 14711-14715.
[6] P.Wahnón, P.Palacios, J.J.Fernández and C.Tablero, " Ab-initio spin polarized electronic structure calculations for TixGanAsm photovoltaic materials ", Journal of materials Science 40, 2005, pp.1383-1386.

[7] P.Palacios, P.Wahnón and C.Tablero, "Ab initio phonon dispersion calculations for TixGanAsm and TixGanPm compounds ", Computational Material Science 33, 2005, pp.118-124.

[8] K. M. Yu,W.Walukiewicz, J. W. Ager, III, D. Bour, R. Farshchi, O. D. Dubon,S. X. Li, I. D. Sharp, E. E. Haller, " Multiband GaNAsP quaternary alloys",Appl. Phys. Lett. 88, 2006, 092110

[9] W. Wang, A. S. Lin, J. D. Phillips, "Intermediate-band photovoltaic solar cell based on ZnTe:O",Applied PhysicsLetters 95, 2009, 011103.

[10] S.Silvestre, J.Puigdollers, A.Boronat and L.Castañer, "Analysis of GaAs-Ti thin films deposited by sputtering onto c-Si and GaAs", 7th IEEE Spanish Conference on Electron Devices, 2009, pp. 5-7.

[11] Benachir El Hadadia, Herve Carchanob, Jean-Luc Seguinb, Hassan Tijanic, "Structural and electrical properties of amorphous $\mathrm{GaAs}$ sputtered at high substrate temperature $\left(220\right.$ and $\left.400{ }^{\circ} \mathrm{C}\right) "$, Vacuum 80,2005 , pp. 272-283. 